\title{
Hepatitis A Viral Load Measurement
}

National Cancer Institute

\section{Source}

National Cancer Institute. Hepatitis A Viral Load Measurement. NCI Thesaurus. Code C92541.

The determination of the HAV viral load in a specimen. 